\title{
Influence of Different Factors \\ on Tree Growth of Pinus sibirica in the Highlands of the Central Altai Mountains
}

\author{
Svetlana A. Nikolaeva*, \\ Dmitry A. Savchuk and Anatoly Yu. Bocharov \\ Institute of Monitoring of Climatic \\ and Ecological Systems SB RAS \\ 10/3 Academichesky prospect, Tomsk, 634055, Russia
}

Received 19.04.2015, received in revised form 27.05.2015, accepted 22.08.2015

The effect of environmental factors on basal area increment and tree ring width chronologies in Siberian stone pine (Pinus sibirica Du Tour) trees of primary communities at the upper forest belt on the Severo-Chuisky Range in the Central Altai Mountains (the foreland Aktru) were analyzed. These chronologies reflect both age patterns of growth and effect of environmental factor sets (biogeocoenotic, edaphic, and climatic). Age patterns of growth are lower amount of the basal area increment and higher angle value between increment trend and the abscissa axes in younger trees and vice versa in older trees. Competition among trees reduces the increment of suppressed trees of different generations. Portion of stands with the higher density increases downwards the valley. Covering the tree stems by small and mid-size disintegrated rock formations occurred repeatedly and caused reduction of their ring width to one-second to one-fifth of the width in the uncover trees during 40-70 years. Climatic factors influence directly (early summer temperature) and indirectly (by additional cooling effect of the glaciers depending on winter precipitation value, solar radiation, and growing season temperature) on tree growth. Ratio between the direct and the indirect climatic effect on maximal basal area increment changes downwards the valley and in the course of time.

Keywords: potential productivity, basal area increment, tree ring width, internal factors, environmental factors, Siberian stone pine, Pinus sibirica.

DOI: $10.17516 / 1997-1389-2015-8-3-299-318$.

(C) Siberian Federal University. All rights reserved

* Corresponding author E-mail address: sanikol1@rambler.ru 


\title{
Влияние различных факторов \\ на прирост деревьев Pinus sibirica \\ в высокогорных лесах Центрального Алтая
}

\author{
С.А. Николаева, Д.А. Савчук, А.Ю. Бочаров \\ Институт мониторинга климатических \\ и экологических систем СО РАН \\ Россия, 634055, Томск, пр. Академический, 10/3
}

Рассмотрено влияние биогеоченотических, эдафических и климатических факторов на динамику прироста по радиусу и площади поперечного сечения ствола укедра сибирского (Рinus sibirica Du Tour), произрастающего в верхней частигорно-лесного пояса Северо-Чуйскогохребта Центрального Алтая (горно-ледниковый бассейн Актру). Установлено, что в древесно-кольцевых хронологиях кедра выражены как возрастные особенности роста, так и влияние различных экологических факторов. Возрастные особенности прироста по площади сечения ствола у кедра характеризуются низкой скоростью в начальный период роста, высоким ускорением в молодом возрасте и относительно высокой скоростью и низким ускорением в более старшем возрасте. Конкурентные взаимоотношения между деревьями, усиливающиеся при повышении густоты древостоев, приводят к снижению прироста у угнетенных деревьев разных поколений. Засыпание оснований стволов деревьев мелко- и среднеобломочным материалом приводит к снижению радиального прироста в 2-4 раза на протяжении 40-70 лет. Климатические факторы воздействуют на прирост деревьев как прямо (раннелетняя температура), так и косвенно благодаря охлаждающему влиянию ледников (динамика последних зависит от количества зимних осадков, солнечной радиации и температуры вегетачионного сезона). Вклад прямого и косвенного влияния климатических факторов на максимальный прирост по площади сечения изменяется при движении вниз по долине и с течением времени.

Ключевые слова: прирост ствола дерева по радиусу и площади поперечного сечения, влияние внутренних, биогеоченотических, эдафических и климатических факторов, Pinus sibirica, Алтай.

\section{Введение}

При реконструкции климатических условий в прошлом на основе анализа динамики радиального прироста древесных растений обычно используются стандартизированные древесно-кольцевые хронологии. У древесных растений, произрастающих в экстремальных условиях местообитания, обычно обнаруживаются достаточно тесные связи между радиальным приростом и параметра- ми климата (Ваганов и др., 1996). Но при этом нередко встает проблема потери информации о долговременных колебаниях. Поэтому идет поиск новых методов расчета индексов прироста для выявления длительных изменений климата (Briffa et al., 1998; Наурзбаев, 2007).

Возрастные особенности прироста деревьев в лесоведении оцениваются по динамике их стволовой биомассы. Поскольку прямые измерения погодичной биомассы дерева тру- 
доемки, то для ее оценки используют косвенные методы. Нарастание годичной стволовой биомассы деревьев в лесной таксации определяется через объемный прирост стволовой древесины, который функционально связан с ростом кроны и корневой системы. Достоверным косвенным показателем объемного прироста является прирост по площади поперечного сечения ствола, который по сравнению с радиальным приростом лучше отражает возрастные особенности накопления стволовой биомассы деревьев и древостоев (Cilliers, van Wyk, 1938; Уткин, 1975; Гортинский, Тарасов, 1969; Фильрозе, 1987; Алексеев, Лайранд, 1993; Усольцев, 1997 и др.). Прирост по площади поперечного сечения ствола стал применяться особенно активно в последние десятилетия как один из возможных индикаторов климатических изменений (Гортинский, Тарасов, 1969; Briffa et al., 1998; Agrawal, 1995; Шашкин, Ваганов, 2000; Jump et al., 2006; Black et al., 2008 и др.).

Высокая скорость роста деревьев реализуется в оптимуме их произрастания при соответствии генетической программы деревьев и благоприятных почвенно-климатических условий (Полюшкин, 1987 и др.). Поэтому ряд максимальных значений прироста деревьев в лесных сообществах по сравнению с рядом средних значений при достаточно большой выборке может характеризовать потенциальную возможность их прироста в данных экологических условиях и служить для выявления отклика древесного ценоза на внешние воздействия (Бузыкин и др., 1986; Дашковская, 1989).

В высокогорьях древесные виды чутко реагируют на климатические изменения. Кроме того, здесь их прирост зависит и от других экологических факторов - оползней, селей, ветрового режима, пожаров и т.п. (Горчаковский, Шиятов, 1985; Ваганов и др., 1996). К со- жалению, роль последних редко обсуждается в дендроклиматической литературе. Цель нашего исследования - выявить основные факторы, влияющие на прирост деревьев кедра сибирского (Pinus sibirica Du Tour) в верхней части горно-лесного пояса на примере горноледникового бассейна Актру.

\section{Объекты и методы}

Район исследования - северный макросклон Северо-Чуйского хребта Центрального Алтая, верховья р. Актру (5004' с.ш., 8745' в.д.). Максимальные абсолютные высоты достигают здесь 4075 м. В районе имеются крупные ледники. Климат этого района резко континентальный. По данным метеостанции Актру (2150 м), он характеризуется низкими среднегодовыми (минус 5,2 ${ }^{\circ} \mathrm{C}$ ) и летними (7,7-9,6 ${ }^{\circ} \mathrm{C}$ в июне-августе) температурами воздуха, коротким вегетационным периодом (число дней со средней суточной температурой выше $5{ }^{\circ} \mathrm{C}-52$ дня), высокими значениями суммарной солнечной радиации, особенно в летние месяцы (около 540 МДж/м²) и количеством осадков около 560 мм. Сумма положительных температур выше $10{ }^{\circ} \mathrm{C}$ составляет $1127^{\circ}$ (Тронов и др., 1965; Севастьянов, 1998; Тимошок и др., 2009а).

По лесорастительному районированию район исследований относится к ЦентральноАлтайской котловинно-горной провинции лиственничных и темнохвойных лесов (Крылов, Речан, 1967). В этом бассейне лесная растительность произрастает в виде непрерывной полосы по днищу долины р. Актру от верховьев до устья. Верхняя граница сомкнутых лесов из кедра и лиственницы поднимается до высоты 2220-2300 м, групп деревьев, образующих лесные микрогруппировки, - до 2390 м, отдельно растущих деревьев - до 2420-2475 м. Верхняя граница леса относится к двум экологическим типам - термическому 
и эдафическому (Тимошок и др., 2009б). Особенностью верховий долины р. Актру является то, что концы ледников спускаются ниже верхней границы леса.

Коренные леса сохранились на высотах от 2300 до 2150-2100 м, ниже располагаются производные леса, неоднократно пройденные пожарами. Первые представлены в основном кедровыми и лиственничнокедровыми, реже лиственничными абсолютно-разновозрастными древостоями. Продолжительность жизни кедра здесь доходит до 600 лет, и он формирует древостои с участием деревьев двух-четырех поколений. Вторые - лиственничными, кедроволиственничными, реже лиственничнокедровыми ступенчато-разновозрастными и условно-одновозрастными древостоями. В долине реки на флювиогляциальных отложениях произрастают условно-разновозрастные лиственничники (Бочаров, 2011; Тимошок и др., 2009б). Почвы под коренными лесами представлены горными криоземами, реже дерново-подбурами. В случае, когда поверхности участков леса сверху перекрыты делювиальными крупнозернистыми отложениями, на их поверхности сформированы примитивные щебнистые криоземы с маломощным почвенным профилем (Воробьев и др., 2001; Давыдов, Тимошок, 2010).

К неблагоприятным погодноклиматическим факторам в горно-ледниковом бассейне Актру можно отнести: (1) короткий вегетационный период, (2) резкие перепады сезонных и суточных температур и освещения, высокую вероятность заморозков и снегопадов в течение всего лета, (3) высокие значения ультрафиолетовой радиации. Кроме того, к факторам, прямо или косвенно влияющим на рост древесной растительности, относятся: (1) ледники, внедряющиеся в лесной пояс, (2) землетрясения, камнепады, сели, ла- вины и обвалы, (3) каменистость субстрата и несформированность почв, (4) пожары.

Объектами нашего исследования являлись коренные леса в верхней части лесного пояса горно-ледникового бассейна Актру, образованные кедром сибирским и лиственницей сибирской (Larix sibirica Ledeb.).

В верховьях р. Актру заложен экологический профиль, охватывающий все основные местообитания кедра и лиственницы, от фрагментов лесных сообществ, расположенных на расстоянии 0,5 км от современного конца языка ледника Малый Актру (абсолютная высота 2300 м), до лесных массивов, расположенных на расстоянии 4 км от ледника вниз по долине (2100 м).

В нашем сообщении использованы данные, полученные на 9 постоянных пробных площадях (ПП), представленных коренными сообществами, расположенными на расстоянии 0,5-2,4 км от конца языка ледника Малый Актру, на высотах 2150-2300 м над ур.м. (табл. 1, рис. 1). Лесные сообщества представлены как небольшими участками (ПП № $2 \mathrm{~A}, 2 Б, 11 Б, 11 \mathrm{~B})$, так и крупными массивами (ПП № 4Б, 4В, 5, 8, 10). Древостои неоднородны по своей структуре. По данным прироста деревьев с девяти ПП построено 6 древеснокольцевых хронологий по кедру (данные с близко расположенных ПП 2А и 2Б, 11Б и 11В, 4Б и 4В были объединены).

Для построения этих хронологий использовали керны, взятые у взрослых деревьев в нижней части ствола $(0,4-1,3$ м), а также спилы, взятые у молодых особей в основании стволиков. Ширина годичных колец измерялась по двум или четырем радиусам с помощью измерительного комплекса LINTAB с точностью 0,01 мм. После получения индивидуальных древесно-кольцевых серий проводилось их перекрестное датирование с помощью сочетания кросскорреляци- 
Таблица 1. Характеристика коренных сообществ в верхней части лесного пояса горно-ледникового бассейна Актру (Северо-Чуйский хребет, Центральный Алтай)

\begin{tabular}{|c|c|c|c|c|c|c|c|c|c|c|c|}
\hline № ПП & 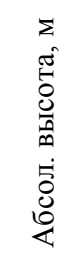 & 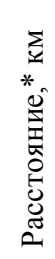 & 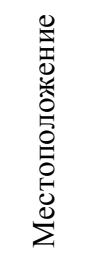 & 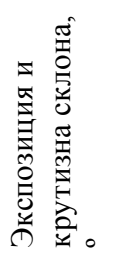 & 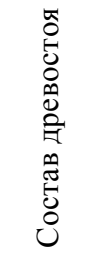 & 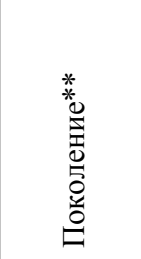 & 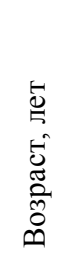 & 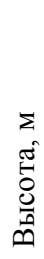 & 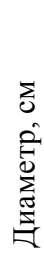 & 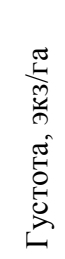 & 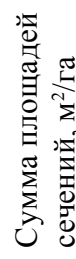 \\
\hline $2 \mathrm{~A}$ & 2300 & 0,5 & $\mathrm{M}_{1}$ & $\mathrm{CB} 6^{\circ}$ & $10 \mathrm{~K}$ & $\begin{array}{c}\mathrm{I} \\
\mathrm{II} \\
\text { Всего } * * *\end{array}$ & $\begin{array}{l}470 \\
275\end{array}$ & $\begin{array}{l}14 \\
12\end{array}$ & $\begin{array}{l}68 \\
50\end{array}$ & $\begin{array}{c}90 \\
80 \\
170\end{array}$ & $\begin{array}{l}23 \\
11 \\
35\end{array}$ \\
\hline $2 Б$ & 2300 & 0,5 & $\mathrm{M}_{1}$ & $\mathrm{CB} 6^{\circ}$ & $10 \mathrm{~K}$ & $\begin{array}{c}\text { I } \\
\text { II } \\
\text { III } \\
\text { Всего }\end{array}$ & $\begin{array}{c}458 \\
270 \\
99\end{array}$ & $\begin{array}{c}12 \\
9 \\
6\end{array}$ & $\begin{array}{l}44 \\
32 \\
15\end{array}$ & $\begin{array}{c}33 \\
92 \\
133 \\
\mathbf{2 5 8}\end{array}$ & $\begin{array}{c}5 \\
6 \\
2 \\
13\end{array}$ \\
\hline $11 \mathrm{~B}$ & 2280 & 0,7 & Л & Ю $30^{\circ}$ & $10 \mathrm{~K}$ & $\begin{array}{c}\text { I } \\
\text { II } \\
\text { III } \\
\text { Всего }\end{array}$ & $\begin{array}{c}527 \\
330 \\
80\end{array}$ & $\begin{array}{c}20 \\
15 \\
9\end{array}$ & $\begin{array}{l}78 \\
45 \\
22\end{array}$ & $\begin{array}{c}52 \\
26 \\
51 \\
\mathbf{1 2 9}\end{array}$ & $\begin{array}{c}25 \\
4 \\
2 \\
\mathbf{3 1}\end{array}$ \\
\hline $11 \mathrm{~B}$ & 2300 & 0,7 & Л & Ю $30^{\circ}$ & $10 \mathrm{~K}$ & $\begin{array}{c}\text { I } \\
\text { II } \\
\text { Всего }\end{array}$ & $\begin{array}{c}337 \\
85\end{array}$ & $\begin{array}{c}13 \\
9\end{array}$ & $\begin{array}{l}43 \\
23\end{array}$ & $\begin{array}{c}56 \\
490 \\
\mathbf{5 4 3}\end{array}$ & $\begin{array}{c}8 \\
21 \\
29\end{array}$ \\
\hline $4 Б$ & 2200 & 0,9 & $\Pi \mathrm{M}_{2}$ & C3 $5-7^{\circ}$ & 8К2Л & $\begin{array}{c}\text { I } \\
\text { II } \\
\text { III } \\
\text { Всего }\end{array}$ & $\begin{array}{l}455 \\
277 \\
128\end{array}$ & $\begin{array}{l}19 \\
15 \\
12\end{array}$ & $\begin{array}{l}58 \\
41 \\
22\end{array}$ & $\begin{array}{c}47 \\
50 \\
73 \\
\mathbf{2 5 0}\end{array}$ & $\begin{array}{c}12 \\
7 \\
3 \\
29\end{array}$ \\
\hline $4 \mathrm{~B}$ & 2200 & 0,9 & $\Pi \mathrm{M}_{2}$ & C3 $5-7^{\circ}$ & 8 К $2 Л$ & $\begin{array}{c}\text { I } \\
\text { II } \\
\text { III } \\
\text { Всего }\end{array}$ & $\begin{array}{r}460 \\
280 \\
110\end{array}$ & $\begin{array}{c}16 \\
13 \\
9\end{array}$ & $\begin{array}{l}72 \\
43 \\
20\end{array}$ & $\begin{array}{c}71 \\
59 \\
200 \\
377\end{array}$ & $\begin{array}{c}28 \\
9 \\
6 \\
46\end{array}$ \\
\hline 5 & 2160 & 1,5 & Л & ЮB $25^{\circ}$ & 8К2Л & $\begin{array}{c}\text { I } \\
\text { II } \\
\text { III } \\
\text { Всего }\end{array}$ & $\begin{array}{l}409 \\
309 \\
132\end{array}$ & $\begin{array}{l}22 \\
19 \\
13\end{array}$ & $\begin{array}{l}59 \\
39 \\
18\end{array}$ & $\begin{array}{c}32 \\
75 \\
277 \\
\mathbf{4 0 6}\end{array}$ & $\begin{array}{c}9 \\
9 \\
8,5 \\
\mathbf{2 9}\end{array}$ \\
\hline 10 & 2190 & 1,9 & $\Pi$ & C3 $20^{\circ}$ & 7КЗЛ & $\begin{array}{c}\text { I } \\
\text { II } \\
\text { III } \\
\text { Всего }\end{array}$ & $\begin{array}{l}485 \\
353 \\
213\end{array}$ & $\begin{array}{l}19 \\
17 \\
11\end{array}$ & $\begin{array}{l}94 \\
56 \\
28\end{array}$ & $\begin{array}{c}27 \\
16 \\
59 \\
\mathbf{1 4 9}\end{array}$ & $\begin{array}{c}18 \\
4 \\
3,5 \\
\mathbf{3 6}\end{array}$ \\
\hline 8 & 2150 & 2,4 & $\Pi$ & B $18^{\circ}$ & 7КЗЛ & $\begin{array}{c}\text { I } \\
\text { II } \\
\text { III } \\
\text { Всего }\end{array}$ & $\begin{array}{c}497 \\
156 \\
74\end{array}$ & $\begin{array}{c}11 \\
10 \\
6\end{array}$ & $\begin{array}{l}68 \\
30 \\
10\end{array}$ & $\begin{array}{c}67 \\
89 \\
200 \\
\mathbf{5 0 0}\end{array}$ & $\begin{array}{c}24 \\
6 \\
2 \\
\mathbf{4 2}\end{array}$ \\
\hline
\end{tabular}

Примечание: * расстояние от конца современного языка ледника Малый Актру; ** только для поколений кедра; *** суммарно для всего древостоя (кедр и лиственница). Л, П - левый и правый борта долины, $\mathrm{M}_{1}-$ на морене исторической стадии ледника Большой Актру, $\mathrm{M}_{2}-$ у правой части фронтальной морены ледника Малый Актру конца XVIII - начала XIX в. К - кедр, Л - лиственница.

онного анализа (Holmes, 1983) и графической перекрестной датировки (Douglass, 1919). Для построения хронологий индексов прироста выполнялась процедура стандартизации с помощью программы CRONOL (Methods..., 1990; Holmes, 1992). 


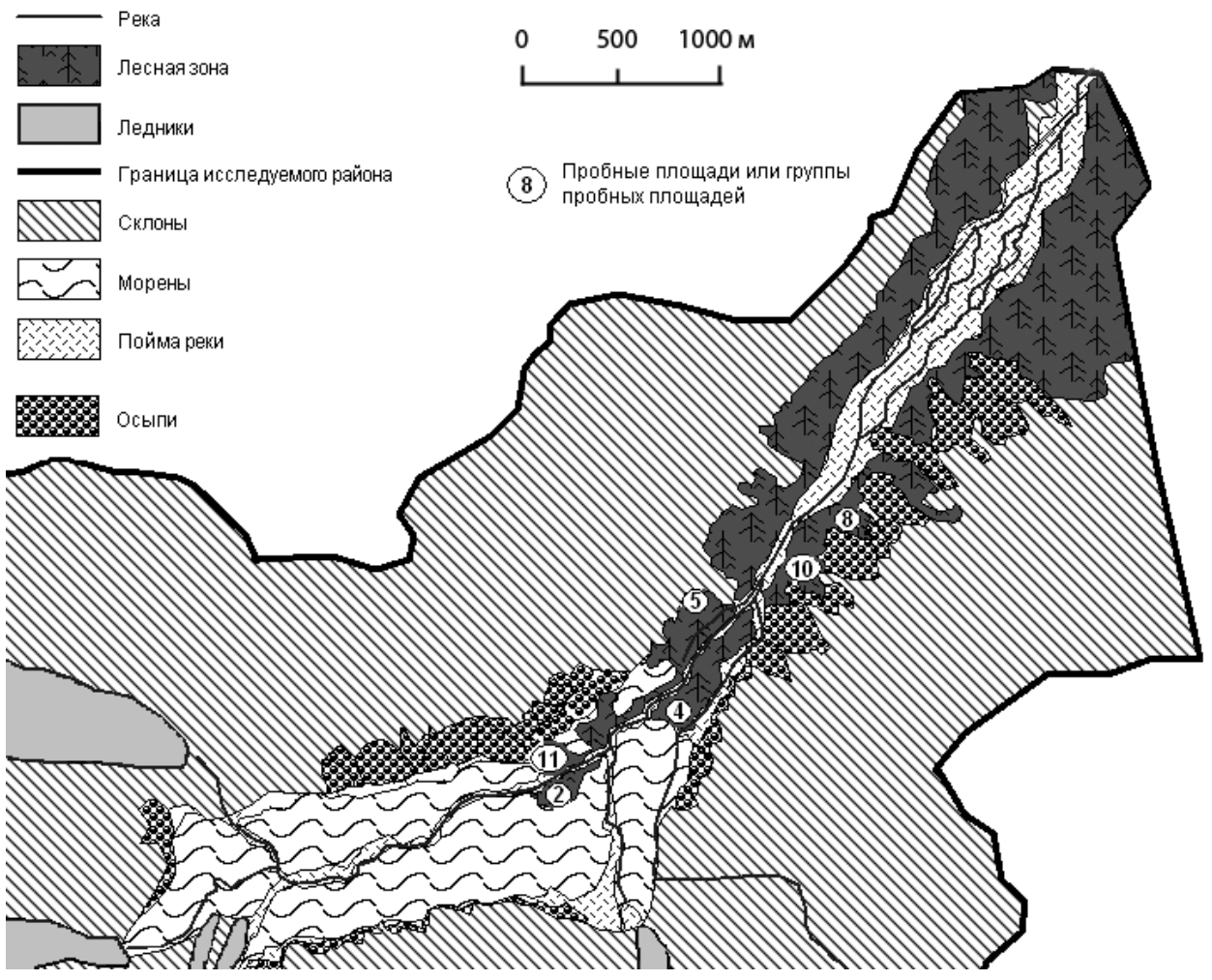

Рис. 1. Карта-схема района исследований (горно-ледниковый бассейн Актру, Северо-Чуйский хребет, Центральный Алтай) с расположением постоянных пробных площадей. Карта-схема составлена А.С. Кузнецовым. Нумерация пробных площадей - см. табл. 1. На рисунке указаны только осыпи, прилегающие к участкам леса, не отмечены области селей и лавин

Прирост по площади поперечного сечения ствола $\left(\mathrm{Z}_{\mathrm{S}}\right)$ дерева рассчитывали по осредненным сдатированным данным радиального прироста двух (керны) или четырех (спилы) радиусов. При этом учитывали диаметр ствола в месте взятия керна, длину радиусов от первого подкорового годичного кольца до сердцевинного. Если керн проходил мимо сердцевины или имелась сердцевинная гниль, то в этом случае местоположение сердцевины определялось расчетным путем. Во всех случаях измерялся или восстанавливался отрезок радиуса от центра (реального или восстановленного) до ближайшего кольца, с которого начинались подсчеты $Z_{\mathrm{S}}$. Построение большого количества индивидуальных рядов $Z_{\mathrm{s}}$ позволило нам сделать следующий эмпирический вывод. Особое внимание следует уделять определению длины начального (околосердцевинного) отрезка радиуса, который используется как отправная точка для дальнейших расчетов ежегодно нарастающего радиуса и площади ствола (Савчук, Николаева, 2011).

Кроме того, в работе использованы данные по землетрясениям, произошедшим на территории бывшего СССР (Новый..., 1977). Из них с помощью компьютерной программы с учетом энергетического класса землетрясения и расстояния от его эпицентра до верховьев р. Актру (Malyshkov, Malyshkov, 2012) были выбраны землетрясения, значимые для исследуемого района. 


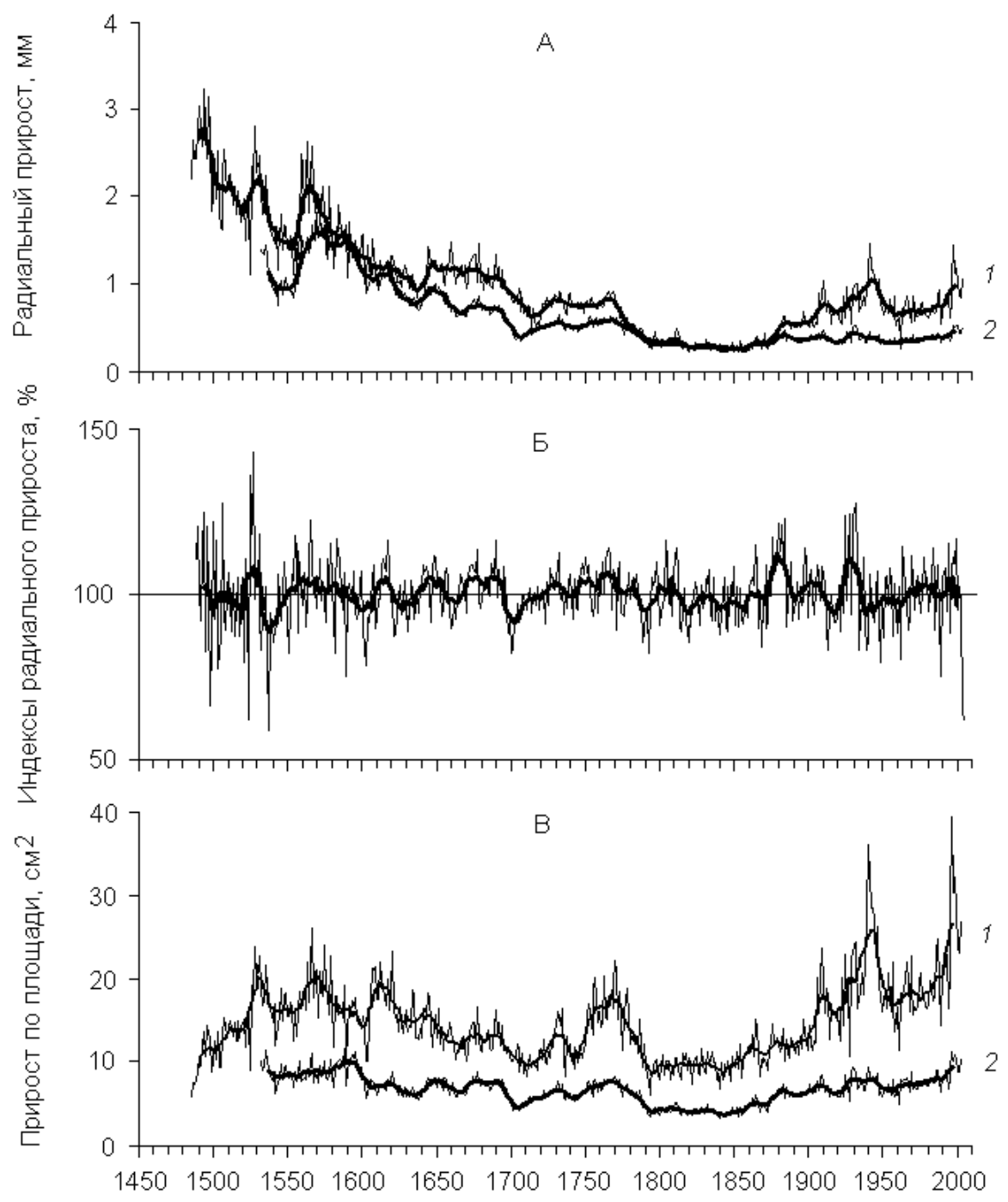

Рис. 2. Разные виды древесных хронологий кедра $(\mathrm{N}=8)$, построенных на примере одного из коренных кедровников (ПП № 4Б, 4В) горно-ледникового бассейна Актру: А - радиальный прирост; Б - индексы радиального прироста; В - прирост по площади поперечного сечения ствола; 1 - максимальный; 2 - средний. Полужирная линия - осреднение с шагом 11 лет

\section{Результаты и обсуждение}

Предварительный анализ исходных данных по радиальному приросту и построенных древесно-кольцевых хронологий для старовозрастных деревьев кедра показал, что они несут информацию о разных процессах (рис. 2). Кривая радиального прироста имеет форму части параболы с удлиненной правой частью. Она отражает в первую очередь возрастные особенности радиального роста де- рева: вначале происходит увеличение прироста (отсутствует на графиках из-за наличия сердцевинных гнилей), затем его снижение и, наконец, относительная стабилизация прироста на более или менее низком уровне (рис. 2А). Резкое увеличение и снижение прироста характерно для молодых особей, его стабилизация - для взрослых деревьев. Их кратковременные и долговременные колебания отражают влияние внешних факторов. 
Эти особенности прироста особенно четко фиксируются по их максимальным значениям (рис. 2A, 1).

Считается, что колебания индексов радиального прироста в основном отражают влияние внешних факторов. У кедра амплитуда их долговременных колебаний незначительная (рис. 2Б), что связано с более низкой чувствительностью кедра к этим факторам по сравнению с лиственницей. Тем не менее отклонения величин индексов в последние два столетия не столь велики, как можно было бы предположить, исходя из отклонений средних температур за последние полтора века, рассчитанных для Северного полушария (IPCC, 2001).

$\mathrm{B}$ динамике $Z_{S}$, как и в динамике радиального прироста, прослеживаются возрастные особенности роста и колебания, вызванные воздействием факторов внешней среды (рис. 2B). S-образная форма кривой с удлиненной правой частью в изменении $Z_{S}$ деревьев больше соответствует возрастной динамике нарастания фитомассы стволовой древесины дерева по сравнению радиальным приростом.

Длина начального отрезка кривой прироста, значения которого существенно отличаются по величине и тренду от остальной части возрастной кривой, для радиального прироста намного больше, чем для $\mathrm{Z}_{\mathrm{s}}$. Различия сохраняются примерно до 1650 и 1530 гг. соответственно (рис. 2А, В). При синхронных погодичных колебаниях средних и максимальных значений прироста (радиального и $Z_{\mathrm{S}}$ ) разница в величине между ними, особенно заметная в долговременной динамике (рис. 2, 1-2), показывает влияние факторов, не связанных с климатическими колебаниями.

Ежегодная продуктивность (или чистая первичная продукция) деревьев зависит от большого количества внутренних и внешних факторов. Она в соответствии со схемой А.И. Бузыкина (2007), регулируется на пяти уровнях: генетическом, физиологобиохимическом, биоценотическом, эдафическом и климатическом.

\section{Генетический $u$ физиолого-} биохимический уровни регулирования (внутренние факторы роста) продуктивности деревьев представляют собой реализацию программы роста и развития растений, записанной в генотипе, а также взаимодействие всех органов и систем (Бузыкин, 2007). Основные особенности роста деревьев кедра, выявляемые на дендрохронологическом материале в лесных сообществах на Западно-Сибирской равнине и в верхней части горно-лесного пояса Северо-Чуйского хребта, описаны нами ранее (Николаева, Савчук, 2009; Савчук, Николаева, 2011 и др.).

В горно-ледниковом бассейне Актру во всех сообществах на графиках $Z_{\mathrm{S}}$ у деревьев разного возраста выделяется большое количество этапов роста по скорости (абсолютная величина $Z_{\mathrm{s}}$ ), ускорению (угол наклона тенденции к оси абсцисс) и флуктуациям (амплитуда и длина цикла) роста (рис. 3). У 50-100-летних деревьев хорошо прослеживается начальный отрезок возрастной кривой с низкой скоростью и высоким ускорением роста. Это деревья третьего поколения и крупный подрост, который начинает внедряться в подчиненную часть древостоя. У деревьев старше 200 лет в большинстве случаев начальных отрезков кривой нет из-за наличия сердцевинных гнилей или отсутствия сердцевины на керне. В дальнейшем у них выделяется большое количество этапов роста, которые отличаются друг от друга по скорости и ускорению роста. Эти показатели роста у деревьев кедра могут изменяться в различных типах условий местопроизрастания. Следует также отметить, что формы кривых средних 


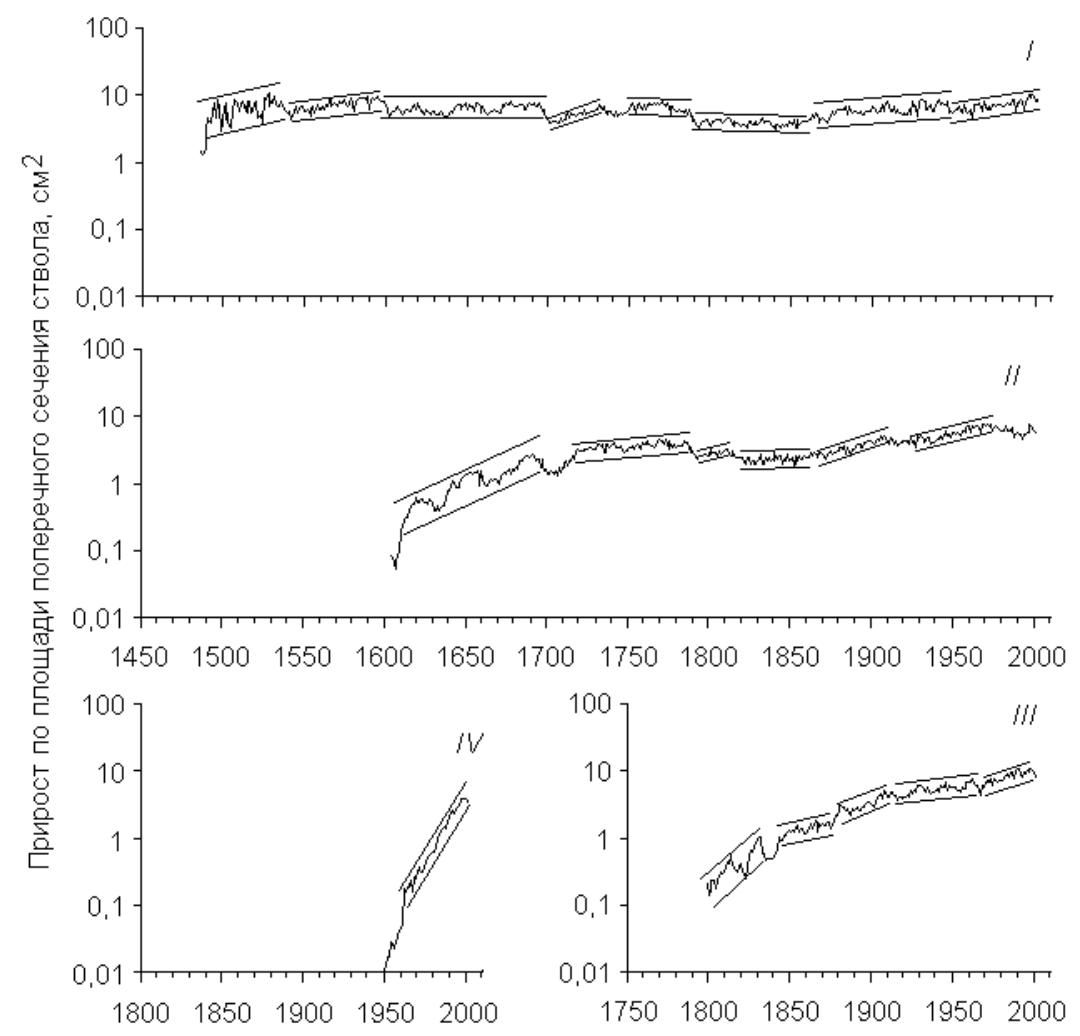

Рис. 3. Возрастная динамика средних значений прироста по площади поперечного сечения ствола деревьев кедра разных поколений в одном из коренных лиственнично-кедровых сообществ (ПП № 4Б, 4B): $I-I I I-$ поколения деревьев, $I V$ - крупный подрост

и максимальных значений $Z_{\mathrm{S}}$ деревьев разных поколений повторяют друг друга, а разница в величине может доходить до двух-трех раз.

Биоценотический уровень включает в себя меж- и внутривидовые взаимодействия, смены поколений деревьев и их ценозов (Бузыкин, 2007). Конкуренция между деревьями одного и разных поколений одного вида и между разными видами, как правило, приводит к задержке развития, снижению размеров и показателей прироста (Савчук, Николаева, 2011). При увеличении густоты древостоев приросты в толщину у угнетенных деревьев снижаются. При этом в разновозрастных древостоях с более высокой густотой доля угнетенных деревьев всех поколений по сравнению с разреженными возрастает.
Достижение максимальных значений $\mathrm{Z}_{\mathrm{S}}$ деревьями разных поколений во времени также зависит от густоты древостоев. Первоначально максимальные значения $Z_{\mathrm{S}}$ дают деревья только первого поколения (поскольку живые деревья предыдущих поколений отсутствуют): до 1800-1900 гг. в разреженных древостоях и до 1900-1970 гг. в более густых. В дальнейшем максимальных значений достигают деревья первого и второго поколений попеременно. В густых древостоях эта особенность сохраняется до настоящего времени, в разреженных - максимальные значения во второй половине XX в. могут давать деревья третьего поколения и даже крупный подрост, внедряющийся в подчиненную часть древостоя. Высокие потенциальные возможности 
деревьев разных поколений, особенно во второй половине столетия, в разреженных древостоях, по-видимому, связаны с благоприятными климатическими условиями, которые способствуют реализации ростовой функции у крупных деревьев разного возраста.

Эдафический уровень регулирования продуктивности лесных сообществ определяется разными типами почв и их трансформацией на различных местообитаниях (Бузыкин, 2007). В частности, четко прослеживается реакция деревьев на резкое увеличение отложений обломочного материала. Это явление мы исследовали в одном из массивов леса, расположенном у правой части фронтальной морены ледника Малый Актру, образовавшейся в конце XVIII - начале XIX в. (рис. 1, табл. 1, ПП № 4Б). Нижние части стволов деревьев, растущих по периферии данного массива со стороны склона, занесены слоями мелко- и среднеобломочного материала толщиной от
0,3 до 1,5 м. Почвенный разрез ${ }^{1}$ до глубины 1,8 м около 450-летнего дерева кедра показал, что на засыпанной части ствола имеется пять уровней придаточных корней: два основных (на глубине 1,4-1,5 и - 0,0-0,2 м) и три промежуточных (на глубинах 0,25, 0,6 и 1,3 м). Если учитывать эти пять уровней корней, то это дерево на протяжении своей жизни было засыпано не менее четырех раз слоями обломочного материала толщиной $12,66,38$ и $23 \mathrm{~cm}$.

Деревья с засыпанными основаниями стволов отличаются более низкими значениями радиального прироста от контрольных деревьев близкого возраста как из этого же (ПП № 4В), так и из других (ПП № 2A, 2Б) участков леса (рис. 4). Промежуток времени, когда наиболее заметны эти различия, охватывает годы с 1750-х по 1970-й. На этом отрезке можно выделить четыре периода с продолжительным снижением прироста за-
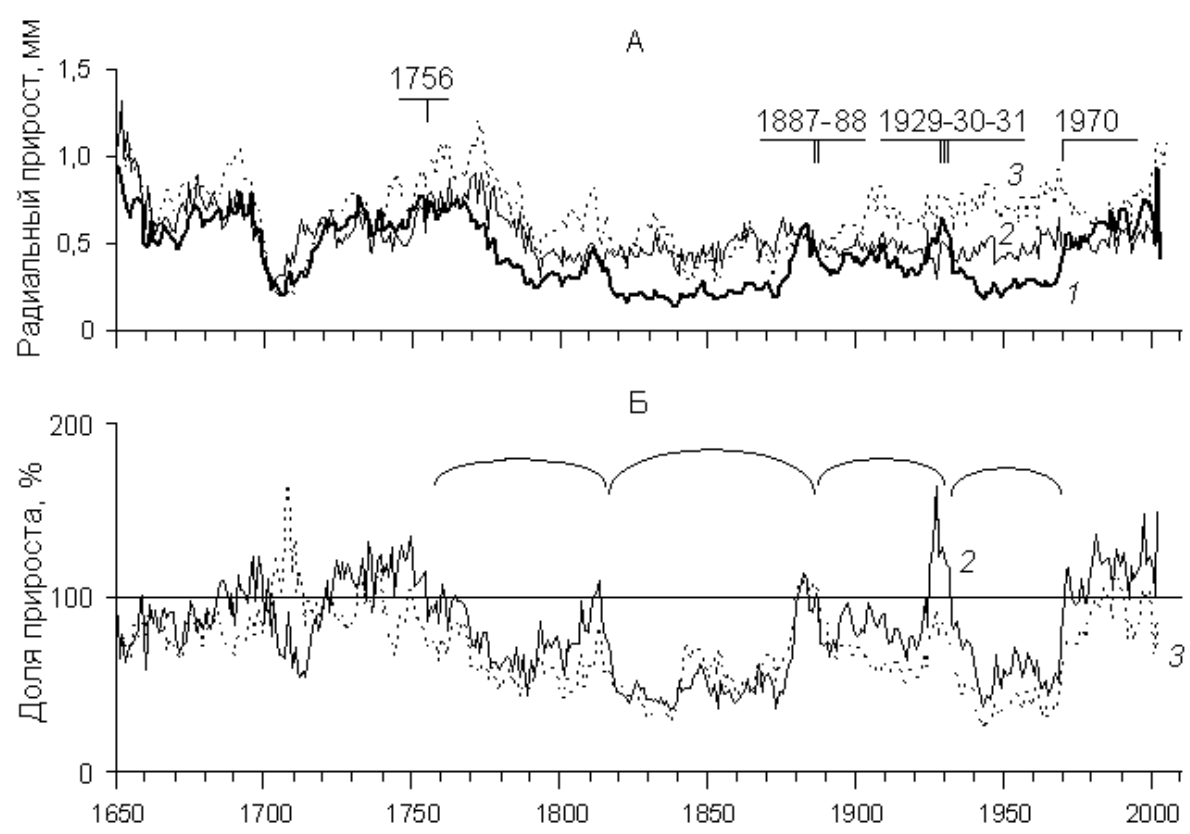

Рис. 4. Древесно-кольцевые хронологии засыпанных (1 - ПП № 4Б) обломочным материалом деревьев кедра по сравнению с незасыпанными (2 - ПП № 4В, 3 - ПП № 2А, 2Б): А - абсолютные, Б - относительные величины. Вертикальными черточками обозначены землетрясения, предшествовавшие долговременному снижению прироста; дугами - периоды пониженного прироста 
сыпанных деревьев и его восстановлением в конце каждого из них длительностью 57, 73, 43 и 38 лет (1756-1813, 1814-1887, 1888-1931 и 1932-1970 гг.). Еще один период продолжительностью 76 или 65 лет (1681-1755 гг. по радиусу со стороны склона горы и 1690-1755 гг. по радиусу со стороны лесного массива) фиксируется в секторах ствола обследованного дерева на глубине 1,2 м и не фиксируется на вышерасположенных (Николаева, Савчук, 2012). Поскольку у кедра корневая система поверхностная, то такие снижения прироста вызваны не только его повреждениями, но и резким ухудшением почвенного режима (изменения аэрации, влажности, температуры и микробиологической активности) после засыпания оснований стволов деревьев, а в дальнейшем отмиранием не только сосущих, но и ростовых корней и тратой пластических веществ на их восстановление. Увеличение прироста в конце каждого периода связано с полным или частичным восстановлением корневой системы на новом уровне.

Таким образом, существенные снижения прироста засыпанных деревьев фиксируют достаточно резкие «одномоментные» увеличения толщины отложений мелко- и среднеобломочного материала, который поступал с окружающих склонов, в том числе с потоком протекающего рядом ручья. Роль последнего для деревьев, растущих по периферии данного участка леса (ПП № 4Б), велика, поскольку с конца 1970-х гг., когда было отведено русло ручья, долговременные снижения прироста не наблюдались.

Подготовка обломочного материала осуществляется в результате морозного и инсоляционного выветривания, его движение - снежными лавинами, а при оттаивании - водой (Титова, Петкевич, 1964; Кузнецов, Невидимова, 2010). Движение обломочного материала вниз по склонам могло активизироваться зем- летрясениями. За период с 1750 по 1970 г. из примерно двух тысяч выделенных землетрясений, которые теоретически могли вызвать начало этого процесса в горно-ледниковом бассейне Актру, трем долговременным снижениям прироста изученных деревьев (с 1757, 1888 и 1932 гг.) предшествовали достаточно сильные землетрясения (в 1756, 1887-1888, 1929-1931 гг.). Землетрясения после 1970 г. уже не отражались на их приросте, т.к. активное поступление обломочного материала с водным потоком заметно уменьшилось. Долговременному снижению прироста с 1814 г. мы не нашли предшествующих ему землетрясений соответствующей силы. Это могли быть землетрясения, произошедшие на территории Монгольского Алтая и не отраженные в каталоге, охватывающем территорию бывшего СССР (Новый..., 1977). Возможно, если обломочного материала образовалось достаточно, его передвижение вниз по склону не обязательно может быть обусловлено землетрясением, достаточно оттаивания грунтов. Следует также отметить, что после землетрясений 1681 и 1691 гг. резкий спад прироста по двум радиусам обнаружен на засыпанной части ствола модельного дерева на глубине 1,2 м и отсутствует выше, а после землетрясения 1756 г. он отмечается в части ствола в районе современного уровня почвы.

Таким образом, долговременное снижение прироста у части деревьев кедра, растущих по периферии лесных массивов со стороны склонов, может быть вызвано их засыпанием обломочным материалом в результате переноса последнего водой или снежными лавинами, а повышенная сейсмическая активность лишь активизирует этот процесс.

Климатический уровень включает в себя радиационный, газовый и ветровой режимы, количество осадков, соотношение тепла и влаги (Бузыкин, 2007). Ранее было установ- 
лено, что в горно-ледниковом бассейне Актру основным климатическим фактором, лимитирующим прирост деревьев лиственницы (Душкин, 1965; Панюшкина, Овчинников, 1999; Панюшкина и др., 2000; Ойдупаа и др., 2004; Мыглан и др., 2009) и кедра (Душкин, 1965; Воробьев и др., 2002; Бочаров, 2011), является раннелетняя температура (май-июль у разных авторов). Реже отмечается влияние температуры и осадков зимы (Панюшкина и др., 2000). Исходя из этого, мы рассмотрели изменение максимальных значений $Z_{\mathrm{S}}$ кедра как возможного индикатора раннелетних температур воздуха. Во всех локальных хронологиях кедра на кривых $Z_{\mathrm{S}}$ имеются участки, абсолютные значения или направленность в изменении которых близки между собой. Это, по-видимому, является отражением сходной реакции хорошо растущих деревьев разного возраста на одни и те же внешние факторы.

В начальный период роста деревьев большинство локальных хронологий $Z_{\mathrm{S}}$ имеют низкую скорость и высокое ускорение (рис. 5, 1a). Такие особенности прироста характерны для молодых деревьев. Полностью этот отрезок кривой представлен в хронологии № 2, отчасти № 10 и конец отрезка - в остальных хронологиях. В одном из сообществ (ПП № 5) низкие скорость и ускорение роста на начальном отрезке кривой в течение длительного времени (рис. 5, 1б), скорее всего, связаны с сильным угнетением молодого поколения со стороны деревьев верхнего яруса вследствие высокой сомкнутости верхнего полога. Еще в одном сообществе начальный отрезок кривой $Z_{\mathrm{S}}$ плохо обеспечен материалом (ПП № 8) из-за наличия сердцевинных гнилей ствола у большинства изученных деревьев.

Более высокие значения прироста деревьев в большинстве сообществ с конца XIX до начала XX в. (рис. 5, 2a) четко фиксируют современное потепление климата. Причем максимальные значения $Z_{\mathrm{S}}$ в это время в основном обеспечиваются деревьями в воз-
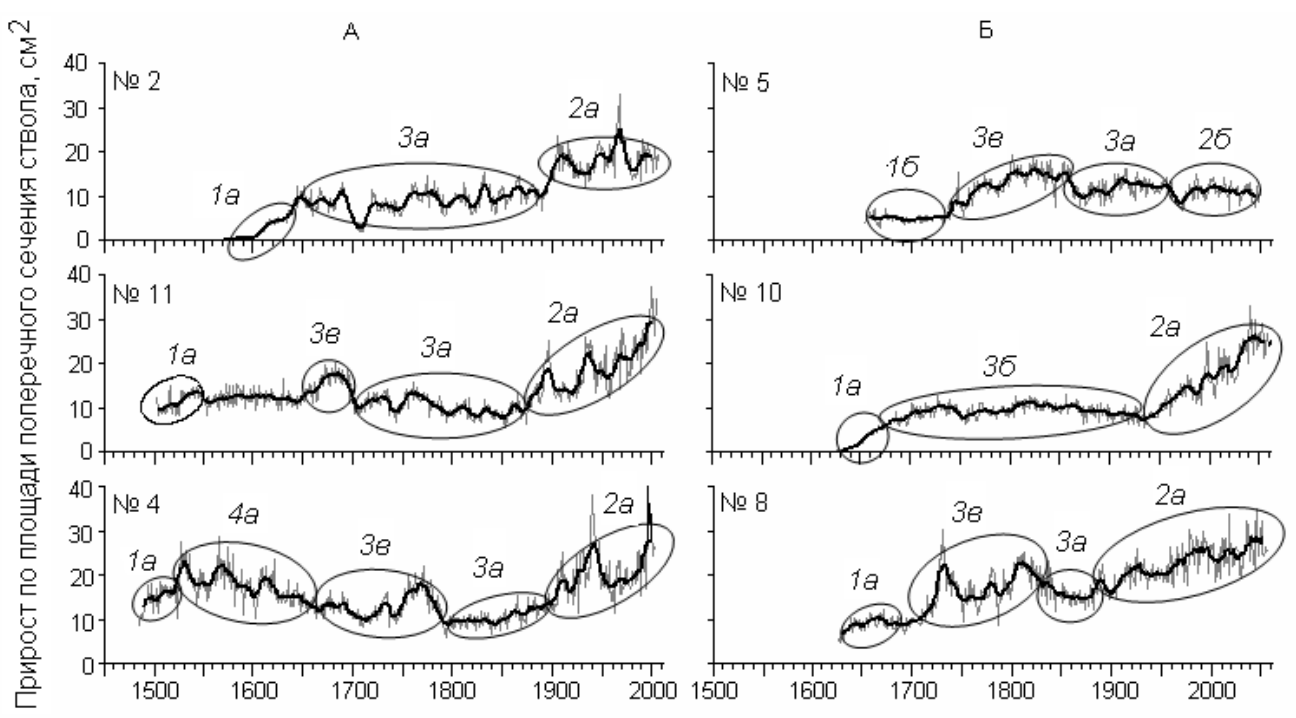

Рис. 5. Локальные хронологии максимальных значений прироста по площади сечения ствола кедра из коренных сообществ горно-ледникового бассейна Актру. Древостои: А - приледниковые, Б - долинные. Овалами выделены временные отрезки кривых, отражающие те или иные особенности роста деревьев (1-4, a-6 - объяснения по тексту). Тонкими линиями показаны погодичные данные прироста, полужирной - сглаженные с шагом в 11 лет 
расте 80-120 лет. Исключение составляет сообщество в средней части профиля (ПП № 5), в котором низкие величины $Z_{\mathrm{S}}$ в $\mathrm{XX}$ в. (рис. 5, 2б) могут быть обусловлены сильной конкуренцией между деревьями всех ярусов в результате высокой густоты древостоя или же недостатком материала по молодым деревьям. Кроме того, в одном из сообществ (ПП № 4) удалось найти деревья, у которых максимальные значения $Z_{\mathrm{S}}$ в XVI и первой половине XVII в. по величине близки к таковым в XX в. (рис. 5, 4a). Это может указывать на долговременное потепление климата.

Низкие значения $Z_{S}$ деревьев во всех сообществах в XVII-XIX вв. (рис. 5, 3a) отражают более низкие величины значений раннелетних температур. Продолжительность этого периода увеличивается при приближении к современному концу языка ледника Малый Актру: с двух-трех десятилетий в древостое из нижней части профиля (ПП № 8) до двух с половиной веков в древостоях из верхней части профиля (ПП № 2А, 2Б). Эти различия вызваны охлаждающим эффектом ледников (Подрезов, 1962; Душкин, 1965) на приледниковые сообщества (ПП № 2A, 2Б, 11Б, 11В и 4Б, 4В). Чем дальше от ледника расположены участки леса, тем дольше у хорошо растущих деревьев сохраняется повышенный прирост в XVII-XIX вв. (рис. 5, 36). Исключением является сообщество (ПП № 10), расположенное достаточно далеко от ледника, в котором период с низкими значениями $Z_{\mathrm{S}}$ составляет около двух с половиной столетий (рис. 5, 36). Конкуренция как возможный фактор низких значений исключается, т.к. большинство деревьев растет одиночно. Поскольку данное сообщество расположено на участке склона в основании конуса осыпи, то плохой рост деревьев здесь, возможно, вызван их засыпанием обломочным материалом не только в верхней части, но и по всей его площади. Это предположение требует дальнейшей проверки.

В целом величина максимального $Z_{S}$ деревьев увеличивается при движении вниз по склону, достигая наибольших значений в сообществе (ПП № 8) на высоте 2150 м. Особенно заметны различия в величине прироста между локальными хронологиями в XVII-XIX вв., которые практически исчезают во второй половине XX в. Увеличение потенциально возможного прироста деревьев кедра как во времени (особенно во второй половине $\mathrm{XX}$ в. в большинстве изученных сообществ), так и в пространстве (вниз по экологическому профилю) отражает улучшение термического режима и связанные с ним изменения других показателей лесорастительных условий. В верховьях р. Актру, скорее всего, наблюдаются процессы, близкие к тем, что проходят на верхней границе леса на Южном Урале (Kammer et al., 2009). Повышение среднегодовой температуры воздуха на $1,8{ }^{\circ} \mathrm{C}$, высоты снежного покрова и количества осадков за последние 78 лет на Южном Урале стимулировало микробиологическую активность почвы, что способствовало увеличению скорости разложения органических остатков, обогащению почвы азотом и, как следствие, увеличению прироста ели.

Таким образом, как индивидуальные серии радиального прироста и $Z_{\mathrm{S}}$, так и хронологии $Z_{\mathrm{S}}$ на разных временных отрезках отражают влияние климатических и неклиматических факторов. При этом долговременные колебания климата последних столетий фиксируются в большинстве локальных хронологий, но имеются особенности, связанные с расположением участков по отношению к ледникам.

Ледники оказывают охлаждающее влияние на окружающие территории, снижая температуру воздуха в летние месяцы 
на $0,5-4{ }^{\circ} \mathrm{C}$ на расстоянии $150-160$ м от открытых ледниковых языков и до 300-400 м при ледниковом ветре (Подрезов, 1962; Душкин, 1965; Тронов и др., 1965; Севастьянов, 1998). Тем самым они могут влиять на рост деревьев, оказавшихся в непосредственной близости от них. Установлено, что максимальное продвижение ледников Актру вниз по долине за последние 500 лет соответствует фронтальной морене ледника Малый Актру середины XIX в. (Душкин, 1965) или, по уточненным данным, морене конца XVIII начала XIX в. при окончательном отступании ледника в первой половине XIX в. (Назаров, Агатова, 2008). Поэтому с учетом местоположения лесных сообществ по отношению к ледникам и характера динамики и величины максимальных значений $Z_{\mathrm{S}}$ деревьев эти сообщества и соответствующие им локальные хронологии были объединены в две группы: приледниковые и долинные (рис. 6А). В приледниковую хронологию вошли три локальные хронологии, построенные для сообществ, расположенных на расстоянии 0,5-0,9 км от современного конца языка ледника и на высоте 2300-2200 м (№ 2, 11 и 4), в долинную - три хронологии в 1,5-2,4 км и 2190-2150 м соответственно (№ 5, 10 и 8). Лесорастительные условия сообществ приледниковых и долинных лесов по продуктивности эдафотопа и степени воздействия климата в целом должны иметь большое сходство между собой внутри групп и отличаться между группами.

С учетом обеспеченности хронологий материалом (рис. 6Б) более или менее достоверно они отражают динамику потенциально возможной продуктивности коренных лесов с начала (приледниковая) и середины (долинная) XVII в. До этого времени значения $Z_{S}$, скорее всего, занижены, поскольку они относятся к очень молодым на тот момент деревьям (их величины существенно ниже, чем у более взрослых), и отсутствуют данные по
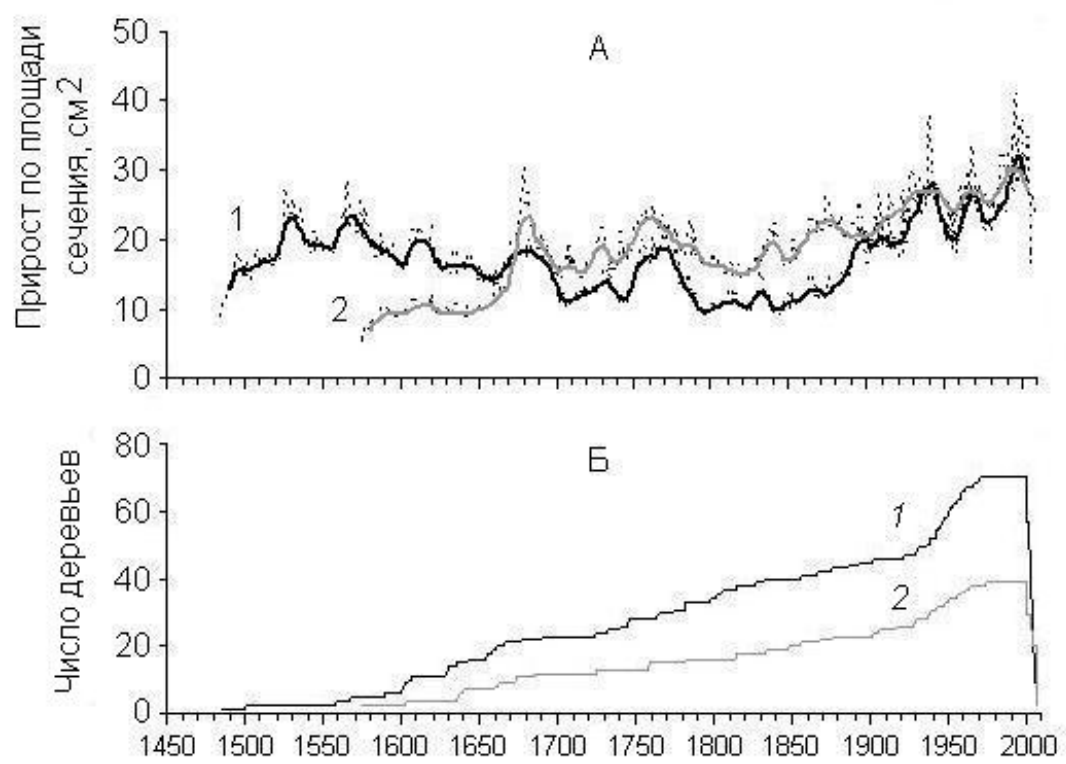

Рис. 6. Приледниковая (1) и долинная (2) хронологии максимальных значений прироста по площади поперечного сечения ствола кедра горно-ледникового бассейна Актру: А - хронологии, Б - количество модельных деревьев. Остальные обозначения см. рис. 5 
деревьям более старшего на тот момент возраста.

При сравнении приледниковых и долинных хронологий между собой выделяются три периода: первый - 1650-1780, второй - 17801890 и третий - 1890-2000 гг. Наибольшая разница в величине $Z_{\mathrm{S}}$ между этими хронологиями наблюдается во втором периоде (при похолодании климата), наименьшая - в третьем (при потеплении). В период наибольшего наступания ледника Малый Актру в XIX в., когда все приледниковые сообщества оказались в непосредственной близости от него, наибольшая разница в величинах $Z_{\mathrm{S}}$ приледниковых и долинных хронологий отражает не только снижение температуры воздуха вегетационного сезона, вызванное похолоданием климата, но и дополнительный охлаждающий эффект ледника на приледниковые сообщества. Нарастание массы ледников и их продвижение вниз по долине происходит при снижении солнечной радиации, температуры и увеличении количества зимних осадков (Тронов, 1973; Дроздов, Мосолова, 1973). А само продвижение языка ледника Малый Актру по долине за последние 500 лет фиксируется в трех приледниковых хронологиях
(№ 2, 11 и 4). В период наибольшего отступания ледников в $\mathrm{XX}$ в. наименьшая разница в величинах $Z_{\mathrm{S}}$ между этими хронологиями отражает в основном колебания температуры воздуха.

Таким образом, обобщенные хронологии максимальных значений $Z_{\mathrm{S}}$, отражающие долговременную динамику потенциально возможного прироста деревьев кедра коренных лесов, позволяют оценивать прямое и опосредованное влияние климата на рост деревьев при существенном снижении роли факторов неклиматической природы. Прямое воздействие климата отмечается в долинных хронологиях за последние 500 лет и в приледниковых хронологиях в периоды потеплений. Одновременно прямое и опосредованное влияние климата наблюдается в приледниковых хронологиях в периоды похолоданий при увеличении размеров ледников.

Пространственно-временная локализаиия воздействия различных факторов. В горно-ледниковом бассейне Актру на разных участках долины и в различные периоды времени в росте деревьев в толщину фиксируется неодинаковый набор экологических факторов (табл. 2).

Таблица 2. Основные экологические факторы в горно-ледниковом бассейне Актру (Северо-Чуйский хребет, Центральный Алтай), фиксируемые в росте деревьев кедра

\begin{tabular}{|c|c|c|}
\hline Группа факторов & Локализация & № ПП \\
\hline \multicolumn{3}{|l|}{ 1. Климатические } \\
\hline $\begin{array}{l}\text { a) прямое воздействие с учетом } \\
\text { абсолютной высоты (раннелетняя } \\
\text { температура) }\end{array}$ & Весь бассейн & Bce \\
\hline $\begin{array}{l}\text { б) опосредованное влияние (через } \\
\text { охлаждающий эффект ледников) }\end{array}$ & Приледниковые сообщества & $\begin{array}{l}2 \mathrm{~A}, 2 \mathrm{~B}, 11 \mathrm{5} \\
11 \mathrm{~B}, 4 \mathrm{5}, 4 \mathrm{~B}\end{array}$ \\
\hline $\begin{array}{l}\text { 2. Эдафические (передвижение } \\
\text { обломочного материала водой, селями, } \\
\text { лавинами, ледниками) }\end{array}$ & $\begin{array}{l}\text { Сообщества на расстоянии до } 3,4 \text { км по } \\
\text { обоим бортам долины от языка ледника } \\
\text { Малый Актру }\end{array}$ & $\begin{array}{l}\text { Все, кроме } \\
2 \text { Б, 4B }\end{array}$ \\
\hline $\begin{array}{l}\text { 3. Биогеоценотические (меж- и } \\
\text { внутривидовая конкуренция) }\end{array}$ & $\begin{array}{l}\text { Сообщества с высокой густотой древостоя. } \\
\text { Их доля увеличивается вниз по долине }\end{array}$ & $\begin{array}{l}5,8, \text { частично } \\
11 Б, 4 Б\end{array}$ \\
\hline
\end{tabular}


Прямое и опосредованное воздействие климата на рост деревьев на территории бассейна осуществляется дифференцированно. Прямо действующим фактором является раннелетняя температура воздуха, абсолютная величина которой увеличивается, а амплитуда суточных и сезонных колебаний снижается, что приводит к увеличению прироста деревьев по мере продвижения вниз по долине. Косвенно действующим фактором считаются осадки зимнего периода. Накопившееся в горно-ледниковом бассейне Актру количество снега совместно с низкими значениями солнечной радиации и температуры воздуха в летний период способствуют росту массы ледников и продвижению их вниз по долине, что оказывает дополнительный охлаждающий эффект на растущие в приледниковой зоне деревья.

Передвижение обломочного материала вниз по склону в результате обвалов, селей, лавин, текущей водой и ледником наблюдается в районе исторической морены Большого Актру и фронтальной морены Малого Актру конца XVIII - начала XIX в., а также на обоих склонах долины. Крупнообломочный материал, встречая на своем пути деревья, обычно уничтожает их. Мелко- и среднеобломочный материал, если он не уничтожает деревья, а только засыпает поверхность, снижает прирост деревьев, растущих одиночно и биогруппами выше границы сомкнутого леса и в массивах леса, особенно в их верхних частях.

Конкуренция между деревьями усиливается с увеличением густоты древостоев и приводит к снижению прироста угнетенных деревьев всех возрастов. Доля таких сообществ увеличивается на более низких гипсометрических уровнях.

Следует отметить существенное влияние на прирост деревьев еще одного фактора, не рассмотренного в этой статье. В росте дере- вьев, произрастающих в производных сообществах, хорошо видны кратковременные и долговременные последствия пожаров в нижней части рассматриваемого бассейна.

\section{Заключение}

При выявлении климатического сигнала и реконструкции климатических параметров в горно-ледниковом бассейне Актру необходимо учитывать, что на рост деревьев оказывают влияние факторы различной природы: климатические, эдафические, биоценотические и т.п. Вклад этих факторов в прирост деревьев изменяется как во времени, так и в пространстве в зависимости от местоположения лесных сообществ по отношению к безлесным склонам, высоте над уровнем моря, ледникам, возрасту деревьев и структуре лесных сообществ, возможности их засыпания обломочным материалом.

Обобщенные (приледниковая и долинная) хронологии максимальных значений прироста по площади поперечного сечения ствола отражают динамику потенциально возможного прироста деревьев кедра сибирского коренных лесов, зависящую в основном от долговременных колебаний климата. Они фиксируют прямое и опосредованное его влияние. Прямое воздействие климата нашло отражение в долинных хронологиях за последние 500 лет и в приледниковых - только в периоды потеплений. Одновременно прямое и опосредованное влияние климата - в приледниковых хронологиях в периоды похолоданий при увеличении размеров ледников.

Серии прироста засыпанных обломочным материалом деревьев отражают влияние переноса этого материала водой и снежными лавинами и опосредованное воздействие климата, т.к. подготовка материала и его передвижение зависят от солнечной радиации, 
температуры и осадков. Повышенная сейсмическая активность, скорее всего, активизирует процесс этого переноса. Такие деревья, включенные в соответствующие локальные хронологии, будут существенно занижать значения индексов прироста на определенных отрезках времени, тем самым оказывают влияние на результаты реконструкции раннелетней температуры как основного лимити- рующего рост деревьев параметра климата в данном районе.

Использование хронологий, построенных по максимальным значениям прироста по площади поперечного сечения ствола, оказалось эффективным инструментом при разделении факторов климатической и неклиматической природы, а также прямого и косвенного влияния климата.

Почвенный разрез сделан и описан к.б.н. В.В. Давыдовым и к.б.н. С.Г. Копысовым.

\section{Список литературы}

1. Алексеев А.С., Лайранд Н.И. (1993) К методике дендроэкологического анализа. Бот. журн. 78 (10): 103-107.

2. Бочаров А.Ю. (2011) Структура и динамика высокогорных лесов Северо-Чуйского хребта (Горный Алтай) в условиях изменения климата. Вестник Томск. гос. ун-та. 352: 203-206.

3. Бузыкин А.И. (2007) Возможности регулирования продуктивности древостоев. Лесоведение 6: 65-71.

4. Бузыкин А.И., Дашковская И.С., Черкашин В.П. (1986) Динамика радиального прироста хвойных разного ценотического положения в Приангарье. В: Дендрохронология и дендроклиматология. Новосибирск: Наука, с. 79-86.

5. Ваганов Е.А., Шиятов С.Г., Мазепа В.С. (1996) Дендроклиматические исследования в Урало-Сибирской субарктике. Новосибирск: Наука, 246 с.

6. Воробьев В.Н., Бочаров А.Ю., Хуторной О.В., Нарожный Ю.К. (2002) Дендроклиматический анализ радиального прироста кедра сибирского (Pinus sibirica) в горно-ледниковом бассейне р. Актру (Центральный Алтай). В: Основные закономерности глобальных и региональных изменений климата и природной среды в позднем кайнозое Сибири. Новосибирск: Изд-во Ин-та арх. этногр. СО РАН, с. 71-78.

7. Воробьев В.Н., Нарожный Ю.К., Тимошок Е.Е., Росновский И.Н., Давыдов В.В., Бочаров А.Ю., Пац Е.Н., Хуторной О.В., Бокша С.В., Кособуцкая Е.Н. (2001) Экологобиологические исследования в верховьях р. Актру в Горном Алтае. Вестник Томск. гос. ун-та 274: 58-62.

8. Гортинский Г.Б., Тарасов А.И. (1969) О географической сопряженности годичного прироста еловых древостоев в подзоне южной тайги. В: Механизмы взаимодействий растений в биогеоценозах тайги. Л.: Наука, с. 40-50

9. Горчаковский П.Л., Шиятов С.Г. (1985) Фитоиндикация условия среды и природных процессов в высокогорьях. М.: Наука, 209 с.

10. Давыдов В.В., Тимошок Е.Е. (2010) Формирование почв на молодых моренах в бассейне Актру (Центральный Алтай, Северо-Чуйский хребет). Сиб. экол. журнал 3: 505-514.

11. Дашковская И.С. (1989) Временная изменчивость радиального прироста древостоев. В: Факторы продуктивности леса. Новосибирск, с. 90-102. 
12. Дроздов О.А., Мосолова Г.И. (1973) О некоторых причинах колебания таяния ледников. В: Проблемы гляциологии Алтая: Матер. науч. конф. Томск: Изд-во ТГУ, с. 21-27.

13. Душкин М.А. (1965) Многолетние колебания ледников Актру и условия развития молодых морен. В: Гляциология Алтая. Вып. 4. Томск: Изд-во ТГУ, с. 83-101.

14. Кузнецов А.С., Невидимова О.Г. (2010) Энергетическая оценка динамики осыпных аккумулятивных склонов верховий горно-ледникового бассейна р. Актру. Вестник Томск. гос. ун-та 338: 227-229.

15. Крылов А.Г., Речан С.П. (1967) Типы кедровых и лиственничных лесов Горного Алтая. М.: Наука, 224 с.

16. Мыглан В.С., Овчинников Д.В., Ваганов Е.А., Быков Н.И., Герасимова О.В., Сидорова О.В., Силкин П.П. (2009) Построение 1772-летней древесно-кольцевой хронологии для территории Республики Алтай. Известия РАН. Серия геогр. 6: 70-77.

17. Назаров А.Н., Агатова А.Р. (2008) Динамика ледников Северо-Чуйского хребта на Центральном Алтае во второй половине голоцена. Матер. гляциологических исследований 105: 73-86.

18. Наурзбаев М.М. (2007) Проблемы выявления длительных климатических изменений в древесно-кольцевых хронологиях. В: Новые методы в дендроэкологии: Матер. всерос. науч. конф. с междунар. участием. Иркутск, с 122-123.

19. Николаева С.А., Савчук Д.А. (2009). Комплексный подход и методика реконструкции роста и развития деревьев и лесных сообществ. Вестник Томск. гос. ун-та. Биология 2(6): $111-125$.

20. Николаева С.А., Савчук Д.А. (2012) Корневая система и рост кедра сибирского (Pinus sibirica Du Tour) в зоне засыпания обломочным материалом. Мир науки, образования и культуры 4 (35): 318-322.

21. Новый каталог сильных землетрясений на территории СССР с древнейших времен до 1975 г. (1977) Кондорская Н.В., Шебалин Н.В. (ред.) М.: Наука, 536 с.

22. Ойдупаа О.Ч., Ваганов Е.А., Наурзбаев М.М. (2004) Длительные изменения летней температуры и радиальный рост лиственницы на верхней границе леса в Алтае-Саянской горной стране. Лесоведение 6: 14-24.

23. Панюшкина И.П., Адаменко М.Ф., Овчинников Д.В. (2000) Дендроклиматическая сеть Горного Алтая как основа количественной палеогеографической реконструкции климата с высоким временным разрешением. В: Проблемы реконструкции климата и природной среды голоцена и плейстоцена Сибири. Вып. 2. Новосибирск, с. 413-419.

24. Панюшкина И.П., Овчинников Д.В. (1999) Климатически обусловленная динамика радиального прироста лиственницы в Горном Алтае. Лесоведение 6: 22-32.

25. Подрезов О.А. (1962) Особенности режима температуры близ конца ледника Малый Актру. В: Гляциология Алтая. Вып. 2. Томск: Изд-во ТГУ, с. 127-131.

26. Полюшкин Ю.В. (1987) Экологическая интерпретация формы кривых и амплитуд радиального прироста деревьев. В: Дендрохронология и дендроклиматология. Новосибирск: Наука, С.33-39.

27. Савчук Д., Николаева С. (2011) Рост и плодоношение кедра сибирского: Временная изменчивость и взаимосвязь. Saarbrucken: Lambert Acad. Publ., 226 с. 
28. Севастьянов (1998) Климат высокогорных районов Алтая и Саян. Томск: Изд-во ТГУ, 201 с.

29. Тимошок Е.Е., Николаева С.А., Скороходов С.Н., Савчук Д.А., Бочаров А.Ю. (2009а) Особенности онтогенетических состояний генеративного периода Pinus sibirica (Pinaceae) в лесах Центрального Алтая. Раст. ресурсы. 45(1): 3-12.

30. Тимошок Е.Е., Филимонова Е.О., Пропастилова О.Ю. (2009б) Структура и формирование древостоев хвойных в экотоне верхней границы древесной растительности СевероЧуйского хребта (Центральный Алтай). Экология 3: 187-194.

31. Титова 3.А., Петкевич М.В. (1963) Наблюдения над конусами аккумуляции в долине реки Актру. В: Гляциология Алтая. Вып.3. Томск, с. 115-141.

32. Тронов М.В. (1973) Горно-ледниковый бассейн Актру как показатель характерных свойств ороклиматической базы оледенения Алтая. В: Проблемы гляциологии Алтая: Матер. науч. конф. Томск: Изд-во ТГУ, с. 9-20.

33. Тронов М.В., Тронова Л.Б., Белова Н.И. (1965) Основные черты климата горноледникового бассейна Актру. Гляциология Алтая. Вып.4. Томск, с. 3-49.

34. Усольцев В.А. (1997) Биологические аспекты таксации фитомассы деревьев. Екатеринбург: УрО РАН, $216 \mathrm{c}$.

35. Уткин А.И. (1975) Биологическая продуктивность лесов (методы изучения и результаты). В: Лесоведение и лесоводство. Т.1. М., с. 9-189.

36. Фильрозе Е.М. (1987) Выявление и оценка этапов роста деревьев и насаждений. В: Дендрохронологические методы в лесоведении и экологическом прогнозировании. Иркутск: Ин-т геогр. СО РАН, с. 206-208.

37. Шашкин Е.А., Ваганов Е.А. (2000) Динамика прироста площадей сечения стволов у деревьев в разных районах Сибири в связи с глобальными изменениями температуры. Лесоведение 3: 3-11.

38. Agrawal A. (1995) Use of dendrochronological methods to estimate an ecological impact date of the chestnut blight. Virgin. J. Sci. 46(1): 41-47.

39. Black B.A., Colbert J.J., Pederson N. (2008) Relationships between radial growth rates and lifespan within North American tree species. Ecoscience 15(3): 349-357.

40. Briffa K.R., Schweingruber F.H., Jones P.D., Osborn T.J., Harris I.C., Shiyatov S.G., Vaganov E.A., Grudd H. (1998) Trees tell of past climates: but are they speaking less clearly today? Phil. Trans. R. Soc. Lond. B. 353: 65-73.

41. Cilliers A.C., van Wyk J.H. (1938) A mathematical expression for the growth of trees in their dependence on time and density of stocking. Annals of the University of Stellenbosch. 16(A,2): $1-36$.

42. Douglass A.E. (1919) Climatic cycles and tree growth: A study of the annual rings of trees in relation to climate and solar activity. V.1. Washington: Carnegie Inst., $127 \mathrm{p}$.

43. Holmes R.L. (1983) Computer-assisted quality control in tree-ring dating and measurements. Tree-Ring Bull. 44: 69-75.

44. Holmes R.L. (1992) Program CRONOL. Tuscon: Laboratory of tree-ring research, University of Arizona.

45. IPCC (Intergovernmental Panel of Climate Change). Climate change. (2001): The scientific basis. Cambridge. http://www.grida.no/climate/ipcc_tar/vol4/russian/pdf/wg1sum.pdf 
46. Jump A.S., Hunt J.M., Penuelas J. (2006) Rapid climate change-related growth decline at the southern range edge of Fagus sylvatica. Global Change Biol. 12(11): 2163-2173.

47. Kammer A., Hagedorn F., Shevchenko I., Leifeld J., Guggenberger G., Goryacheva T., Rigling A., Moiseev P. (2009) Treeline shifts in the Ural mountains affect soil organic matter dynamics. Global Change Biology 15(6): 1570-1583.

48. Malyshkov Yu.P., Malyshkov S.Yu. (2012) Eccentric motion of the Earth's core and lithosphere: Origin of deformation waves and their practical application: Chapter 6. In: Phillips J.M. (Ed.) The Earth's core: Structure, properties and dynamics. Nova Sci. Publ., p. 115-212.

49. Methods of Dendrochronology: Applications in the environmental sciences (1990) Cook E.R., Kairukstis L.A. (Eds.) Dordrecht-Boston-London: Kluwer Acad. Publ., 394 p. 